\title{
THE GRAND PARIS AND THE NEW MOSCOW: COMPARED PERSPECTIVES
}

\author{
Ch. Vaudelin \\ Peoples' Friendship University of Russia (RUDN University) \\ Miklukho-Maklaya str., 6, 117198, Moscow, Russian Federation
}

\begin{abstract}
This article has the objective of comparing the modernization initiatives conducted in Paris and in Moscow and showing how the political choices shape the urban universe. Here, we discuss the restructuring projects both in terms of institutional policies and transport in the two European metropolises: Moscow and Paris.
\end{abstract}

Key words: Grand Paris, New Moscow, metropolis, institutions, transport, ecology

This article aims to revisit the two capitals in line with Fernand Braudel and Immanuel Wallerstein: A space which concentrates power, riches and a land of individual and collective opportunity. Paris and Moscow are more than simple capitals, they are European metropolises, that is to say, important conurbations which bring together a large population, political responsibilities and economic, financial and cultural activities, and they have a strong influence on their national space and beyond.

Firstly, it is necessary to understand the main administrative difference which separates the functioning of Paris and Moscow. These are two cities that are based on different administrative and political models. Actually, if the New Moscow is built on a self-centered and common model it could be otherwise said that the New Moscow devours the nearby cities, which then become a part of Moscow and are placed under the authority of the Muscovite central government. Paris, on the other hand, follows a different system. The Grand Paris could be considered to be polycentric. The Grand Paris project includes not only central Paris but also the suburban towns that remain outside of the Parisian territory, each of which have their own City Hall.

In France, Paris is the center of everything: Powerful and rich, Paris is the heart of our Jacobin state. But Paris is also a world metropolis. So, Paris often occupies a prominent place in the power and attractiveness rankings among global metropolises: 4th in the Global Network Connectivity Index 2010 classification, 3rd in the Global Power City Index 2011, 3rd in the World City Survey 2010. Meanwhile, this image as well as Paris' attractivity is beginning to show signs of decline [3].

The Grand Paris has not acquired new territory, it is composed of Paris intramuros and existing surrounding territories.

Paris is one of the oldest modern European capitals. It's above all a Global City which since its creation relies on a distinct model. Paris is deeply imprinted in world politics and lays down a model of democratic city since 1789 and the storming of the 
Bastille which symbolizes it. Paris is the heart of the French revolution and as stated by Pierre Rosenvalon "Creating a society of equals" requires going through the management of territories and therefore their democratization. During the Enlightenment, Paris chose a social and urban model for the well-being of its citizens with the invention of the open city and the establishment of urban hygiene guidelines [12]. Then, in the second half of the nineteenth century, Paris renews itself and above all goes through a modernization period with the Haussmann Plan. Paris relentlessly democratizes itself: At times in the political domain (neighborhood councils ...) but also in the field of transportation (accessibility policy ...). The equality of territories and particularly in Paris (the center and its suburbs) is integrated into social and political models. And this is how during the 1960s the first major development works around Paris arise, the city folds out with the creation of "new towns" and the capital finds itself surrounded by a suburban area in need of a connection to its city center prompting the construction of the RER [12]. In Paris then emerges an urban region and an urban middle class with it.

However, in the 90s, Paris' innovative approach to change begins to wane resulting even in talks of a decline and the perception of it as a city museum [12]. The city, unlike London, struggles to reorganize and the new plan for the city (SDRIF) in 1994 is a reiteration of the one from 1965. The transformations seen in Paris should be based on 3 main principles: the changes in economical, social and geographical organization; changes in the way the metropolis is built; accounting for changes in political and democratic landscape. It was not until 2007 that Paris seemed to be reborn when then president Nicolas Sarkozy announced the launch of a project for the Grand Paris. The first laws passed in June of 2010 pertained to the development methods and then in December 2013, laws were passed which pertained to institutional organization. The aspiration of the Grand Paris is to create a metropolis that is democratic, sustainable and whose territories are equal, interdependent and supportive of one another. On March 6, 2013, Jean-Marc Herault, former Prime Minister under François Hollande, presented the draft of the Grand Paris.

The project of the Grand Paris has several components: administrative, institutional, transportation ... Anne Hidalgo, the mayor of Paris, also uses the Greater Paris project to change the status of the city of Paris [16]. Paris has always had a special administrative status which places it under the tutelage of the state. In fact, while in France, mayors are elected since 1887, Paris sees its first mayor elected in 1977. Having always had a complex relationship between the state and the city, Paris has had many conflicts with the state (the Parisian insurrection of 1832, the Paris Commune in 1871 ...). Christophe Charle even talks of a "forced marriage" between the city and the French Nation [4]. Moreover, the police are not managed by the city but by the national government. The districts of Paris could be regrouped in order to rebalance Paris Intramuros. Indeed, it may seem surprising that the 1 st district has 15 times more inhabitants than the 15 th but that each of them counts with an independent administration of an equivalent weight. Even though Paris only counts with one Town Hall, each district has the power of decision over local facilities and delivers an assessment on city planning issues. Finally, Paris is both a city and a department (75), requiring it, for example to vote its budget 
twice. So, in the Grand Paris: there should be a merger of the city and the department, which in any way refers to the same thing (same area, same people ...). The Grand Paris project also aims to create a governance structure involving Paris Intramuros and its suburbs (the Petite Couronne, that is to say, the Hauts-de-Seine, Seine-Saint-Denis and Val-de-Marne) [27]. The law on the modernization of public action and affirmation of metropolises (MAPTAM) created the metropolis of Grand Paris on 27 January 2014. It is the law of 7 August 2015 on the new territorial organization of the Republic which determined the functions and prerogatives of the metropolis. Under article L5219-1 the metropolis of Grand Paris exercises legislation over 4 domains: the development of the metropolitan area, the local housing policy, economic development, social and cultural development and the protection of air and the environment [18]. Its territory can be expanded and other skills can be transferred to it.

Regarding transport, the Grand Paris is a very ambitious project valued at 26 billion Euros. This modernization of the Parisian transit system is essential given that $10 \%$ of its network sees $40 \%$ of national traffic and that in a decade it has seen a traffic increase of $21 \%$ [26]. This project covers several issues: quality of life- which aims to reduce commuting time (today $1 \mathrm{~h} 20 \mathrm{~m}$ per day, in contrast to 10 minutes 60 years ago) [15]. The objective of the Grand Paris is that $90 \%$ of Parisians (Ile de France) should find themselves located within two kilometers of a station. There are also challenges in terms of employment (works will employ between 10,000 to 15,000 people), solidarity (open up the territories) and attractiveness (to appeal to businesses).

This particular component of transport has two aspects: modernization and extension as well as aspects relating to construction.Part of the budget was allocated to the modernization and extension of the existing network. The RER will be modernized and the RER line E will be extended to the west. Line 14 will also be extended in order to connect the center of Saint-Denis Pleyel business center and Orly airport. Line 11 will be extended until Noisy-Champs, a total of $10 \mathrm{~km}$ of additional coverage.

Meanwhile, new lines will be created, prenamed the Grand Paris Express, they will be automated and will travel a total distance of $205 \mathrm{~km}$ and contain 72 stations [14]. Line 15 will form a ring road around Paris, such as the circular line in Moscow in order to decongest the network. The other additional lines will aim to serve the developing territories. Line 16 will connect Noisy-Champs in Saint-Denis Pleyel through the Bourget. Line 17 will link Saint-Denis Pleyel in Mesnil-Amelot through Roissy Charles de Gaulle Airport. Line 18 will provide service to the west, from Orly Airport to Versailles' train station.In addition, a fast train (Charles de Gaulle Express) between the airport in Roissy and the city center will be built in the image of the Aeroexpress in Moscow.

Finally, the Grand Paris project also has an ecological component [13]. Unlike Moscow, which tends to expand; Paris tries to limit the urban sprawl and favors the recycling of already urbanized areas that have been forgotten (old malls, empty office spaces ...). The goal is to preserve farmland and forests around Paris. In addition, the project aims to reduce the emission of greenhouse gases by opting for public transit at the expense of personal vehicles. 
Moscow followed suit on January 13, 2012 by launching an international campaign to ensure that it would become a world city and establish itself as a center for culture, education, tourism and finance. It was Dmitry Medvedev, then president, who in 2011 stated that the capital agglomeration should become "a pleasant city to live in" and launched the project. In March 2013, a Russian delegation even went to Cannes at MIPIM (conference of real-estate professionals in Cannes). More ambitious than the Grand Paris in financial terms, since Moscow's project has a budget of $€ 35$ billion, the path chosen by the Russian city is quite different [8]. Indeed, the city was further enlarged on July 1, 2012 as its territory more than doubled. Moscow has, in fact, annexed 21 communes, the equivalent of 148,000 hectares. If Paris is trying to revisit its borders, Moscow's approach is to revise its own. The territories that have been absorbed by the capital were generally quite lowly populated (about 250,000 people) and not well established: A few university towns and shopping malls could be seen but above all dachas (country houses).

The diagram of the Grand Moscow is completely different than the Grand Paris since everything remains to be done. An underdeveloped territory (in terms of housing, work, transport) has been integrated into the borders of Moscow and which is enough to make it attractive.

Behind this project is a real political will, including that of creating a polycentric city (not in terms of political and institutional choices but in economic terms). The goal is to create business centers to increase the attractiveness of the city but also to ease congestion in Moscow which had within its borders more than 12 million inhabitants in 2012. Finally, there is a social purpose in this New Moscow since the state wants to build 250,000 social housing apartments.

Moscow opts for a mixed solution which ultimately leads to a poorly defined plan, between individual and collective transport. However, discussing the New Moscow separately from the old one is, in my opinion, a mistake. Surely the Russian government is not completely opting for a collective solution for the New Moscow, which seems understandable considering its territory. To understand Moscow as a whole, one must analyze both its current districts as well as the historical ones. From this perspective, the government's choice is clear and they are more in favor of collective transport. There are plans to extend the metro to most areas of the city and a new circular line was opened in 2016. The new line did not dramatically change the situation because the government did not build a line according to the population needs but decided, instead, to use an old freight line. Still, the line somewhat improved the transport situation in the city. Moreover, a lot of projects are being developed with the end user in mind. A third circular line will be constructed, connecting the suburbs- thus eliminating the need to come all the way into the center in order to reach another neighborhood (also outside of the center). We could also talk about the maya ulitsa (my street) project, which aims to highlight the importance of pedestrians and subsequently public transport in the city center. There would be an effort to reorganize the streets while inserting the idea of comfort into this megalopolis. Then, it is easier to understand that Moscow, a world-city, which is composed of a historic part and the New Moscow couldn't be studied separately for it would would definitely lead to mistakes such as believing 
Moscow is not favoring public transport. Of course, it cannot be done everywhere because of the surface area of the New Moscow but in the historical part as well as in the near the New Moscow, the city's representatives really opted in favor of a collective transport solution. The first steps have already been taken in 2016 with the opening of two metro stations, Rumyantsevo and Salarevo, located in the southwest part of the city. The opening of these stations has not only helped decongest the "Yugo Zapadnaya" station but also reduce the traffic at the belt road (MKAD), KievskyShaussée and Leninsky Prospect. In addition, the line will be extended from "Salarevo" to "Kommunarka", an area of modest housing [6]. Line 8 was extended in the New Moscow with the construction of three new stations by 2017 . A total of $45 \mathrm{~km}$ of metro were added as well as land transport lines (bus, tram, trolleybus ...) [22]. However, these stations will serve only a minuscule part of the territory of New Moscow, which is extremely extensive. But unlike the Grand Paris, the Grand Moscow provides road construction for the sorely lacking road infrastructure and parking space in the New Moscow region. Thus about 90 parking areas will be built including an enormous one at the level of "Rumyantsevo" to encourage travelers to continue their journey in public transportation. The construction of $700 \mathrm{~km}$ of new road is planned, including a highway with 10 lanes and 12 smaller roads [5]. But this choice marks not only the desire to create infrastructure but also the difficulty Moscow is having to choose its priority. Moscow opts for a mixed solution which ultimately leads to a poorly defined plan, between collective transport and individual.

In addition to institutional projects aiming to improve the life of residents in European cities, such as Grand Paris and New Moscow; there are also projects to make the areas more accessible, innovative and sustainable. It seems interesting to study the mechanisms established by the citizens and the city government to pursue the same objectives. The citizen initiatives are geared towards finding alternative modes of transportation to then settle problems that remain unsolved, such as traffic jams and pollution. Then several other initiatives should be addressed, that are not necessarily supported by the governments of Paris and Moscow: the bicycle sharing system, carpooling and the availability of electric cars in self-service.

In the case of Paris and its suburbs, it is interesting to analyze the trends of 2014 in terms of transport [1]. In 2014, vehicle circulation in the capital fell by $4 \%$, particularly due to traffic congestion, which is constantly decreasing the circulation speed (at least $30 \%$ in 2014). On the other hand, the use of public transport (bus, tram, metro) is increasing. The largest increase is for the cyclists ( $+8 \%$ in 2014). In 2013, bicycles accounted for 3\% of traffic in Paris, against 4\% in 2014.To ensure this general craze, the city of Paris voted in April 2015 a bicycle plan to create new bike paths (the "Vélo Paris Express") and create two bicycle parking lots under the Gare de Lyon and Montparnasse (with a capacity of 2,000 - 3,000 bikes) to dwindle the current shortage of sites. Christophe Najdovski, the deputy mayor of Paris, says that the choice of public transport and cycling is not only the result of problems that come with private transport but a change in general mentality, shifting towards more ecological solutions, as to prefer carpooling, car sharing, bicycle transport... As for example, the bike self- 
service (vélib) was established in 2007 by the city of Paris and counts with 23,600 bicycles, spread over 1800 bicycle stations available every 300 meters [22]. With this service, since 2007, 614 million kilometers have been traveled in Paris and it counts with 274,000 users per year [18]. In Moscow, bike self-service made its first appearance in 2013, with 2,700 bikes spread over 300 stations [21]. However, unlike Paris, where one can subscribe for a year of service but also take a bicycle without being registered, Moscow requires users to register online in advance in order to rent a bike. At the present day, 900,000 people are registered, an increase of 50\% compared to 2013 , but this remains limited because of the need of registration. In addition, bicycle traffic in Moscow has more to do with tourism. Very few home to work routes are seen, or people using the service to continue a journey started by metro. There are several reasons for this: the first being that Moscow lacks bike lanes, except in touristic or recreational areas (for example, a nice bike path was built by the docks and in Park Kultury but its use is purely recreational). This makes bike traffic dangerous on axes with often more than 4 lanes. The second reason is more simple and can't be resolved through investment: the climate problem. During the winter, bikes are removed from the stations making it is impossible to travel in Moscow by bike during half of the year.

After the Vélib, Autolib appeared in Paris in 2009. It is the largest car-sharing network in the world. We cannot really talk about car sharing in the case of Paris and Moscow, as car sharing is to rent a car and bring it back to where it was taken, while in the case of Autolib, it is possible to park at any station. This distinction allows one to differentiate between two types of consumers:The first type of customer (which brings his car at point A) has a "luxury" pattern of usage of the service while the second type was driven by a need. Despite all, we use the term carsharing but putting aside the need to bring the car back to point A. In 2015, the number of people using this car selfservice (which uses electric cars in its fleet) exceeded five million [19]. 57\% of users frequently use Autolib ( 2 to 3 times a week) and 62\% have used it to go to work [25]. Also, not only is the fleet fully electric, but a hundred percent of the electricity used by Autolib is certified renewable since 2012. The fleet now has 2,500 vehicles spread over 880 stations throughout Ile de France, that being Paris and its suburbs. Also, if Paris has served as a model, the company Bolloré, creator of the project, is now exporting its Autolib, which will soon be circulating in London. Choosing Autolib is based on a combination of factors: the price (cheaper than having a car in Paris for occasional trips), ecological (clean cars) and comfort (reserved parking spaces ...). Also, offered car sharing services are increasing in Paris (eg Zipcar). In addition, an electric scooter is being tested on the streets of Paris since October which could prove to be competition for Autolib. The Cityscoot is a clean option in between Velib and Autolib, combining the advantages of both modes [2]. In Moscow, car sharing has begun to emerge during the summer of 2015. The company Delimobil, supported by the city government began installing its cars throughout Moscow. Meanwhile, in this case, the ecological criterion is not taken into account, since all cars are gas cars but this solution has the advantage of being cheaper than owning their own cars for the Muscovites. The fleet has about 550 cars and a parking lot has recently been opened in Sheremetyevo Airport [9; 24]. It is still too early to take stock of the bike and car-sharing in Moscow but a first remark 
can already be made: the registration process is quite complex and requires a courier to come and give you a key, which tends to limit the use of the service. Finally, to continue developing the Parisian beloved electric means of transportation, on January 12, the Parisian City Hall launched the Belib project: 60 charging terminals of $22 \mathrm{~kW}$ for electric cars will be installed in Paris (four have already been installed) [10]. Moscow, for its part also installs terminals for electric cars since the central government has adopted a policy of support, albeit marginally, to electric vehicles. On November 1, 2015, the first electric charging terminals were installed in gas stations.

Carpooling occupies a central position in the considerations of big metropolises. In June 2014, the Commission of French Sustainable Development published the following report: "Carpooling for commuting: What is the potential?", aiming to define carpooling and the possibility of its use [7]. In France, three million people have adopted carpooling as a means of transportation, of which, 75\% are between 18 and 34 years old [7]. To meet this demand, there are 200 carpool services linking individuals. But the figures for its use in Paris are lacking, as well as the necessary infrastructure since carpooling is still primarily used for long distances. Also, while several regions have set up carpooling areas, Paris has not yet adopted the system. Some motorway management companies, encouraged by the state, have also set up such areas to encourage carpooling doing so prioritizing safety. One can even speak of a beginning of an institutionalization of carpooling matters. Especially since the pollution peaks and application of alternating license plate traffic (even number, odd number) tend to increase usage of carpooling, as seen in March 2014 when the ads on "BlaBlaCar" increased by $17 \%$ and the ones on "Carpooling" $42 \%$ [25]. In Russia, carpooling between major cities is on the rise. BlaBlaCar entered the market in February of 2014 and in the first 10 months, one million people had already registered on the site [11]. However, in Moscow, carpooling remains underdeveloped. There are websites to make commuting like "Dovezu" but the municipality does not support these initiatives and carpooling has not yet been institutionalized.

Finally, if Paris and Moscow have the same objective, that is to say, to modernize the city while making its territory available and attractive, they have certainly chosen to take different paths. The Grand Paris seeks to restructure what already exists, while the New Moscow has engulfed some poorly developed territories to recreate the city. Although, their priorities in terms of transport differ: Paris, with its chasing out of cars and gas vehicles while opting for a policy in favor of public transport, prioritizes public transit while Moscow is far more uncertain, oscillating between public (extension of metro lines ...) and private transport (construction of new roads ...). The New Moscow has not defined a clear priority. It should also be noted that although sharing initiatives (carpooling), exist in both countries, they are far more institutionalized in France than in Russia where they remain quite insignificant. Finally, if Moscow and Paris both have adopted self-service cycling and car sharing their motivations, use and choices are deeply different. Paris defends the ecological aspect (use of Vélib, electric cars in car sharing) they are not found in Moscow, or very little (gas cars used in car-sharing, bike system directed towards tourism ...). 
Modernization is now one of the main goals of megapolises. As an emerging political and economic actor, they have to appear as developed, innovative and attractive cities. However, modernization plans are also a way to cope with the new political challenge of our era, which is climate change and so how to combine big cities and ecology. The third question around city modernization is a democratic one. The city has to be thought for townspeople, for their comfort. How to involve the townspeople and how to put them in the center of the city? In reality, public transport is the one of keys to everything because it is collective, democratic, and ecological.

\section{REFERENCES}

1. B.H. Déplacements à Paris, les vélos dépassent (presque) les autos. Le Parisien. 14.01.2016. Available from: http://m.leparisien.fr/paris-75/deplacements-a-paris-les-velos-depassent-presqueles-autos-14-01-2016-5451447.php. (In Fr.).

2. Bouleau C. Un autolib' version 2 roues à Paris dès 2016? Challenges. 03.12.2015. Available from: http://www.challenges.fr/club-entrepreneurs/20151202.CHA2246/comment-cityscoot-veutimposer-un-autolib-version-2-roues-a-paris.html. (In Fr.).

3. Bourdeau-Lepage L. Introduction. Grand Paris : projet pour une métropole globale. Revue d'Économie Régionale \& Urbaine. 2013; 3 (août). (In Fr.).

4. Charle Ch. Paris fin de siècle, culture et politique. Paris: Seuil; 1998. (In Fr.).

5. Chibanov A. Novaya Moskva stoit na svoem. Moskovskaya Perspektiva. 29.02.2016. Available from: http://www.mperspektiva.ru/topics/9022. (In Russ.).

6. Chmelyova E. Metro oboshlo skorostnoy tramway. Moskovskaya Perspektiva. 29.02.2016. Available from: http://www.mperspektiva.ru/topics/9808. (In Russ.).

7. Commissariat du développement durable. Le covoiturage pour les déplacements domiciletravail: quel potentiel? Juin 2014; 107. (In Fr.).

8. De Rouchebouet Béatrice. Le grand pari de Moscou. Le Figaro. 23.07.2012. Available from: http://www.lefigaro.fr/culture/2012/07/22/03004-20120722ARTFIG00154-le-grand-pari-demoscou.php. (In Fr.).

9. Parkovka v aeroporty Sheremetyevo, Terminal F. Delimobil. 02.03.2016. Available from: https://delimobil.ru/news/parkovka-v-aeroportu-sheremet-evo-terminal-f. (In Russ.).

10. Doche A. Paris: aprèsVelib et Autolib, voici Belic, réseau de bornes de recharge. Caradisiac. 13.01.2016. Available from: http://www.caradisiac.com/Paris-apres-Velib-et-Autolib-voiciBelib-reseau-de-bornes-de-recharge-106237.htm. (In Fr.).

11. Dufay C. Blablacar ne connait pas le crise en Russie. Russie info. 03.1.2015. Available from: http://www.russieinfo.com/blablacar-ne-connait-pas-la-crise-en-russie-2015-10-03. (In Fr.).

12. Gili F. Grand Paris: l'émergence d'une métropole. Paris: Sciences Po Les presses; 2014. (In Fr.).

13. Le Grand Paris: l'environnement. Territoires.gouv.fr. 12 août 2013. Available from: http://www.territoires.gouv.fr/le-grand-paris-l-environnement. (In Fr.).

14. Le Grand Paris: les transports. Territoires.gouv.fr. 03.10.2013. Available from: http://www.territoires.gouv.fr/le-grand-paris-les-transports. (In Fr.).

15. Le Grand Paris: un projet par et pour les franciliens. Territoires.gouv.fr. 9 août 2013. Available from: http://www.territoires.gouv.fr/Le-Nouveau-Grand-Paris-un-projet. (In Fr.).

16. Le rêve d'Hidalgo pour le Grand Paris. Libération. 14 février 2016. Available from: http://www.liberation.fr/france/2016/02/14/le-reve-d-hidalgo-pour-le-grand-paris_1433327. (In Fr.).

17. Loi 2015-991 du 7 août 2015 portant sur la nouvelle organisation territoriale de la République. Available from: https://www.legifrance.gouv.fr/affichTexte.do?cidTexte=JORFTEXT00003098 5460\& categorieLien=id. (In Fr.). 
18. Mairie de Paris. 7 ans de Vélib: des records de fréquentation et d'abonnement. 15.07.2014. Available from: http://blog.velib.paris.fr/blog/2014/07/15/7-ans-de-velib-des-records-defrequentation-et-dabonnements/. (In Fr.).

19. Official Site of car sharing in Paris. Available from: http://www.autolibmetropole.fr/le-serviceautolib/les-chiffres-en-1-clic/. (In Fr.).

20. Official site of Moscow Metro. Available from: http://stroi.mos.ru/razvitie-metro. (In Russ.).

21. Official Site of public bikes in Moscow. Available from: http://velobike.ru/about/news1/. (In Russ.).

22. Official Site of public bikes in Paris. Available from: http://en.velib.paris.fr/. (In Fr.).

23. Razemon O. A quoi sert vraiment une autolib? 10.12.2014. Available from: http://transports.blog.lemonde.fr/2014/12/10/a-quoi-sert-vraiment-une-autolib/. (In Fr.).

24. Poriadka 550 machin mozhno arendovat v Moskve s fevralya. Riamo. 15.02.2016. Available from: http://riamo.ru/happen_news_moscow/20160215/619999132.html. (In Russ.).

25. Russel G. Le pic de pollution dope le covoiturage. Le Figaro. 17.03.2014. Available from: http://www.lefigaro.fr/conjoncture/2014/03/17/20002-20140317ARTFIG00112-le-pic-depollution-dope-le-covoiturage.php. (In Fr.).

26. Un réseau de transport moderne et étendu. Société du Grand Paris. 9 avril 2014. Available from: https://www.societedugrandparis.fr/projet/le-grand-paris/reseau-transport-moderne-etendu. (In Fr.).

27. Paris. Collectivité territoriale spécifique. Vie publique. 15.01.2016. Available from: http://www.vie-publique.fr/decouverte-institutions/institutions/approfondissements/pariscollectivite-territoriale-specifique.html. (In Fr.).

DOI: $10.22363 / 2313-1438-2018-20-2-246-254$

\title{
БОЛЬШОЙ ПАРИЖ И НОВАЯ МОСКВА: СРАВНЕНИЕ ПЕРСПЕКТИВ
}

\author{
Х. Водэлен \\ Российский университет дружбы народов \\ ул. Миклухо-Маклая, 6, Москва, Россия, 117198
}

\begin{abstract}
Целью данной статьи является сравнение программ и инициатив городской модернизации, осуществляемых в Париже и Москве. Автором показано, что политические решения играют ключевую роль в формировании городской среды. В статье рассматриваются проекты реструктуризации транспорта как примеры институциональной политики в двух европейских столицах: Москве и Париже.
\end{abstract}

Ключевые слова: Большой Париж, Новая Москва, столица, институты, транспорт, экология

\section{Сведения об авторе:}

Водэлен Хлое - аспирантка кафедры сравнительной политологии Российского университета дружбы народов (Франция) (e-mail: chloe.vaudelin@hotmail.fr).

\section{Information about the author:}

Vaudelin Chloe - postgraduate student of the Department of Comparative Politics of Peoples' Friendship University of Russia (RUDN University) (France) (e-mail: chloe.vaudelin@hotmail.fr).

Статья поступила в редакцию 21.02.2018.

Received 21.02.2018.

(C) Водэлен Х., 2018. 